\title{
OBITUARIES
}

\section{Charles Baskerville}

Charles Baskerville, chemist, cultured gentleman, and loyal friend, died of pneumonia on the night of January 28 at his home in New York City. For nearly four weeks he had fought a brave but losing fight for his life. The news of his death has brought sadness and a deep sense of personal loss to his friends in many states of the Union and to those outside its bounds who had learned to esteem him and to value his friendship. The mere outline of his life and scientific achievements can tell but part of the story to those who knew him best and were nearest to him.

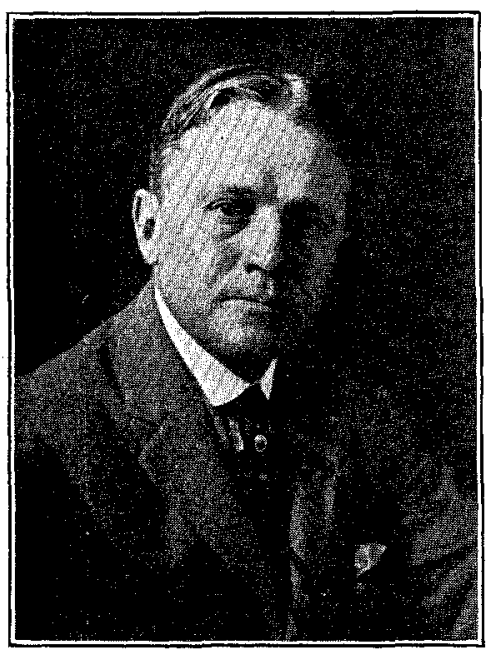

Underwood so Underwood Charless Baskervilite
Dr. Charles Baskerville was born in Mississippi June 18, 1870. Entering the University of Mississippi at sixteen years of age, he completed two years of academic study there. Later he spent a year at Vanderbilt University and further pursued his studies at the University of Virginia, devoting himself especially to the study of chemistry under Mallet. In 1891 , he came to the University of North Carolina as part-time assistant in chemistry and, on completing the requirements, in 1894 received the $\mathrm{Ph} . \mathrm{D}$. degree. While on leave of absence for part of 1893 he studied under Hofmann at the University of Berlin.

During the fourteen years of his connection with the University of North Carolina he advanced from assistant to assistant professor, associate professor, professor, and, from 1900 to 1904 , head of the department of chemistry. He proved himself an able teacher and kept in close touch with his students, showing a keen and sympathetic interest in all that concerned them, especially in their athletic sports where he acted as adviser and friend.

From the beginning of his graduate career he entered with zealous energy upon scientific investigation. 'His special interest lay in the field of the rare earths and many articles were contributed by him to the Society's Journal.

$\mathrm{He}$ became a member of the American Chemical Society in 1894 and later, as councilor and chairman of important committees, rendered much valuable service. He was one of the most constant attendants upon the annual meetings, effectively laboring for the best interests of the Society. He was also a Fellow of the London Chemical Society; a member of the Society of Chemical Industry; of the American Electrochemical Society; of the New York Academy of Sciences; of the Franklin Institute; and of the American Association for the Advancement of Science.

In 1904 he became professor of chemistry and director of the laboratory at the College of the City of New York, designing and supervising the erection of the new laboratory. His interest in research continued, tending more and more to the technical or applied side of chemistry, and this at last practically occupied his attention. In this connection may be mentioned his work on anesthetics, fats, oils, paper recovery, and other important matters. Several books have been published by him, including a text for schools, several for college classes, an account of the investigations upon the radioactive substances, and a volume on anesthetics.

This necessarily brief outline reveals but little of the indomitable energy of the man, his multifarious activities, and the fine service rendered to the communities of which he was at any time a member. Bright, cheery, with most attractive personal characteristics and gifted in many ways, he will be greatly missed and his memory will be kept fresh by his many associates and friends.

F. P. VENABLE

\section{William Frear}

In the early morning hours of January 7,1922 , William Frear died from an apoplectic stroke, suddenly, at his home in State College, $\mathrm{Pa}$. Chemistry lost an indefatigable worker, one of the pioneers of the science as applied to agriculture, in general, and to food production and legal regulation, in particular. His associates lost a zealous and inspiring co-worker, a patient thinker, a prudent counselor, and a true friend.

$\mathrm{He}$ was born March 24,1860, at Reading, $\mathrm{Pa}$, the son of the Rev. George Frear and Malvina (Rowland) Frear. After preparation in the public schools, he studied at Bucknell University (B.A. 1881), Harvard University, and Illinois Wesleyan University (Ph.D. 1883).

On completion of these studies, Dr. Frear immediately entered the government service under the newly appointed Chief Chemist, Dr. H. W. Wiley. In 1885 , he received the appointment of Assistant Professor of Agricultural Chemistry at the Pennsylvania State College where he was soon recognized as a leader in his subject, both in the College and in the State Experiment Station. $\mathrm{He}$ maintained, however, official and active association with the Federal service, doing notable pioneer work in the

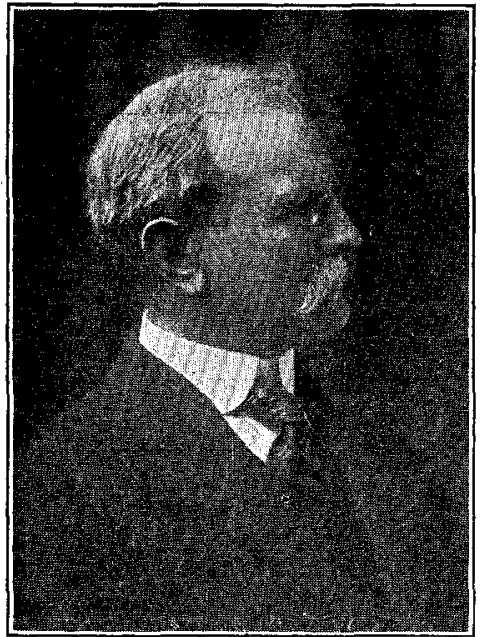

WILLIAM FREAR formative period of the enactment of Food and Drug laws, both State and Federal. As fundamental to and preparatory for this legislation, the Committee on Food Standards was appointed. As chairman of this Committee, it was Dr. Frear's duty to conduct a voluminous correspondence, make extensive literature searches, hold hearings at which antagonistic interests were in action, sift the evidence judicially, and draw a conclusion. The industry, care, thought, and tact which he displayed in this work is probably known only to the very few who 
were closely associated with him. The point of view and method of the scientific investigator is also too generally overlooked in this work. His services were again called for when in 1914 there was established the Joint Committee on Definitions and Standards, of which he was chairman at the time of his death.

As a true pioneer in agricultural college teaching and experiment station work, the scope of his interest and of his scientific production was wide, including meteorology, lime production and use, tobacco culture, soiling crops, composition of foods and feeds, including forage plants, laws to control the production and sale of fertilizers, foods and drugs, and kindred subjects.

The list of scientific societies of which he was a member and the positions of honor and responsibility, which he held in: these societies and in his official life, testify to a life of remarkable breadth and high endeavor.

His social and civic activities were equally broad, keeping him engaged continually for his family, his neighbor, his church, his town, his state, and his country. He well fulfilled the specification of Phillips Brooks for a "four-square man."

IsAac KINg Phelps

\section{Personals}

Charles A. Roos, president of the firm of Charles A. Roos, Inc., 429 East 91st Street, New York, N. Y., manufacturers of copper chemical equipment, died suddenly of heart disease on the afternoon of Wednesday, January 11, 1922, in the New York Athletic Club, of which he had been a member for more than twenty years. Mr. Roos collapsed just as he was about to enter the water of the swimming pool.

Mr. Roos, who was sixty-three years old, was born in New York and was widely known through his various business interests. His firm not only manufactured much of the copper chemical equipment used in synthetic organic chemical mantfacturing plants around New York City, but also produced a large amount of the copper equipment used by the large breweries in this vicinity. It is understood that the business will be carried on under the direction of his son, Mr. Charles A. Roos, Jr., who has been general manager of the concern for some years.

Frank R. Eldred, for many years chief chemist and director of the scientific division of Eli Lilly \& Co., and Frederick C. Atkinson, chemical director of the American Hominy Co. manufacturers of cereal products, vegetable oils, sugars, and sirups, have organized the firm of Eldred and Atkinson, consulting chemists and engineers, with offices at 48 East 41 st St., New York City, and 1857 Gent Ave., Indianapolis. Mr. Eldred will have charge of the New York office while Mr. Atkinson will remain in Indianapolis.

Mr. W. S. Frisbie recently resigned his position as Chief of the Bureau of Food, Drugs and Oil, State Department of Agriculture of Nebraska, to accept an appointment as Chemist in Charge of the Office of Coopperation, Bureau of Chemistry, Washington, D. C.

Mr. Jerome Alexander has recovered from his lengthy iltness and has become president of the Uniform Adhesive Co., Inc., Brooklyn, N. Y., manufacturers of glues, gums, pastes, and adhesives.

Mr. Ernest W. Dean of the Bureau of Mines Experiment Station, Pittsburgh, Pa., has resigned from the Bureat, and is now with The Standard Oil Company of New Jersey.

Dr. Paul E. Klopsteg, formeriy with the Leeds \& Northrup Co., Philadelphia, Pa., is now with the Central Scientific Co., Chicago, I11.

Mr. John P. Harris, chemical engineer for the AllbrightNell Co., formerly of New York, is now located at 829 New York Life Building, Kansas City, where he will represent the Allbright-Nell Company in the southwest.

Dr. W. W. Skinner, Assistant Chief of the Bureau of Chemistry, has been elected chairman of the Joint Committee on Definitions and Standards to succeed Dr. William Frear, deceased.

Mr. E. M. Bailey, Agricultural Experiment Station, New Haven, Conn., has been appointed as the representative of the Association of Official Agricultural Chemists on this committee to fill the vacancy caused by the death of Dr. Frear.

Mr. John Helfrich, who for the past four years served as manager of the Information Bureau of the Chemical Catalog Co., Inc., and who was in charge of the Service Department of THrs JOURNAL, has resigned to establish an office at the Chemists' Club Building, New York City, as a consulting chemist specializing in the development of products that find an application in the leather industry. Prior to his association with the Chemical Catalog Co., Mr. Helfrich was engaged in the leather industry as chemist and assistant plant superintendent.

\section{Industrials}

The Bethlehem Laboratories, Inc., a $\$ 5,000,000$ corporation, has been organized in Pittsburgh to manufacture a new antiseptic, known as hyclorite, which is said to possess 175 times the germicidal strength of hydrogen peroxide. Among the incorporators are Homer D. Williams, president, Carnegie Steel Co.; Taylor Allerdice, vice president, National Tube Co.; and Dr. J. J. Reilly, U S. Shipping Board. The plans of the corporation include the construction of a modern chemical plant in Pittsburgh.

At the annual meeting of the stockholders of Monsanto Chemical Works, the following directors were elected: John $F$. Queeny, Gaston DuBois, Edgar M. Queeny, Theodore Rassieur, H. O. MeDonough, J. D. Lumaghi, and J. R. Goodall. The following officers have been elected for the year 1922: John F. Queeny, chairman of the board; Gaston DuBois, president: H. O. McDonough, vice president; W. R. Phemister, treasurer; Edgar M. Queeny, secretary; C. A. Zacher, assistant secretary.

The Commonwealth Edison Company of Chicago has opened a new $\$ 10,000,000$ power plant, which when completed will generate $250,000 \mathrm{~h}$. p. It is planned later to build another 250,000 h.-p. station on the shores of Lake Michigan at Waukegan, which will fit into a scheme of electric superpower development of Wisconsin, Illinois, and Indiana. The Chicago system. has become the hub of a network of interconnected electric transmission lines in the upper Mississippi Valley which spreads nearly. to Minneapolis on the north, southwest to the Mississippi River, and south to the coal fields of Kentucky.

The Drug and Chemical Section of the New York Board of Trade and Transportation has elected Frank C. Starr, Sharp \& Dohme, chairman; August Wasserschied, Mallinckrodt Chemical Works, vice chairman; William A. Hamann, Roessler \& Hasslacher Chemical Co., treasurer; William F. McConnell, secretary; Clement C. Speiden, Innis Speiden \& Co., representative of the Section in the Board of Trade and Transportation.

E. L. Pierce, president of the Solvay Process Co., Syracuse, N. Y., has resigned, and will be succeeded by E. D. Winkworth, president and executive vice president of the Semet-Solvay Company. Mr. Pierce has also resigned his position as vice president and director of the Allied Chemical and Dye Corporation.

The Dyestuff Department of E. I. du Pont de Nemours \& Co., Inc., has recently been reorganized with a view to the better handling of the technical and commercial probiems of the industry. F. W. Pickard, vice president, has been relieved of his duties on the executive committe to become general manager, with W. F. Harrington as assistant. C. A. Meade; vice president and former general manager, and M. R. Poucher, former director of sales, have been made executive staff officials. Both are directors of the company. Cesare Protto, formerly assistant to Mr. Poucher, has been made director of sales.

The Combustion Engineering Corporation has opened a branch office at 806 First National Bank Building, Pittsburgh, Pa., in charge of $\mathrm{Mr}$. W. C. Stripe, formerly manager of the Philadelphia office.

The National Aniline \& Chemical Co., Inc., has announced the production of two new dyes, National wool green $S$ and National quinoline yellow.

The Argentine Army has just placed its first order for American ammunition with E. I. du Pont de Nemours \& Co. Previously a large part of the army's ammunition was purchased through German concerns. 